\title{
THE INHERITANCE OF BLAST-RESISTANCE IN INDIAN RICE VARIETY, HR-22
}

\author{
Shigehisa Kiyosawa and V.V.S. Murty* \\ National Institute of Agricultural Sciences, Hiratsuka 254
}

\begin{abstract}
Synopsis. The Indian rice variety HR-22 is highly resistant to most of the Japanese strains of the blast fungus. This high resistance was determined to be mainly controlled by the gene $P i-k^{h}$ allelic to the $P i-k$.
\end{abstract}

HR-22 is a variety which has been selected from an Indian variety, Amristari at the Main Experimental Station, Himayetsagar, Hyderabad, India. This variety shows high resistance to most of the Japanese strains of the blast fungus. In the present paper, the results of gene analysis for the blast-resistance of this variety is reported.

\section{Materials and Methods}

Of the plant materials in the first half of the present study, the $F_{1}$ and $F_{2}$ seeds of HR $-22 \times$ Sasashigure and HR $-22 \times$ Koshiji Wase were obtained by Mr. Kotaro NAGAI at the Tohoku Agricultural Experiment Station, and the $F_{3}$ seeds of HR- $22 \times$ Sasashigure by the late P.Y. SHENDGE who had been a trainee from India at the National Institute of Agricultural Sciences in Japan. These hybrid progenies were sown in seedling boxes in a greenhouse. Each $\mathrm{F}_{2}$ population was inoculated twice with two different fungus strains at an interval of one week, first at the 5.3 leaf stage (counted from an incomplete leaf), in order to know the relationship between genes controlling the resistance to the two fungus strains. Injection method was used for inoculation. Method of preparation of spore suspension, inoculation, and rating of resistance were described in detail in the previous paper (Kiyosawa, 1969 b).

During the process of gene analyses of the hybrid of HR-22 and Sasashigure, an effort was made to select lines which showed resist-

Received January 10, 1969

* Agricultural Research Institute, Himayetsagar, Hyderabad, India. ance to a different degree from the parent, HR-22. Among them, a line named K 3 was crossed with some varieties which carried various genes for resistance indentified already. Their progenies were tested for resistance to several fungus strains by spraying method of inoculation.

\section{Results}

\section{A) Gene analysis of HR-22.}

Reactions to seven strains of blast fungus of the varieties used in the present study are shown in Table 1. The $F_{2}$ populations of the hybrid of HR-22 $\times$ Sasashigure showed monogenic segregations for P-2 b, Ina 72 , Ken 54-20 and Ken 54-04 and digenic segregations to Hoku 1 and Ina 168 in the first inoculation (Table 2). In the second inoculation, resistant plants to the first fungus strain in the first and sixth populations in Table 2 showed segregations agreeing with a ratio of $15: 1$ to the second fungus strain, Hoku 1 . If the result of the first inoculation were to be taken as valid, this result indicates that two genes which differ from the gene to the first fungus strain control the resistance to the second fungus strain. The reliability of the $F_{2}$ analysis of this hybrid was, however, not so high as one of the other hybrid progenies which were reported in a previous paper (YAMASAKI and KIYOSAWA, 1966), for there were many intermediate types between $\mathrm{r}$ and $\mathrm{m}$ or $\mathrm{m}$ and $\mathrm{s}$ types of resistance. Therefore, the segregation ratio of $15: 1$ obtained for the second fungus strains does not necessarily indicate any independence or difference of the genes from the genes for resistance to the first strain, although it may suggest two genes 
Table 1. Reactions of varieties used to seven fungus strains of blast fungus

\begin{tabular}{|c|c|c|c|c|c|c|c|c|}
\hline \multirow{2}{*}{ Variety } & \multicolumn{7}{|c|}{ Fungus strain } & \multirow{2}{*}{$\begin{array}{l}\text { Resistance gene } \\
\text { identified to date }\end{array}$} \\
\hline & $\mathrm{P}-2 \mathrm{~b}$ & Ken $53-33$ & Ina 72 & Hoku 1 & Ken $54-20$ & Ken $54-c$ & na 168 & \\
\hline HR-22 & $\mathrm{R}$ & M & $\mathrm{M}$ & $\mathrm{R}$ & $\mathrm{R}$ & $\mathrm{R}$ & $\mathrm{R}$ & ? \\
\hline Sasashigure & $\mathrm{S}$ & $\mathrm{S}$ & $\mathrm{R}$ & $S$ & S & $S$ & $\mathrm{R}$ & $P i-a$ \\
\hline Koshiji Wase & $S$ & $S$ & $S$ & $S$ & $S$ & M & $S$ & $t^{*}$ \\
\hline K 3 & MR & S & $\mathrm{S}$ & $\mathrm{R}$ & $\mathrm{R}$ & $\mathrm{R}$ & $\mathrm{R}$ & ? \\
\hline Shin 2 & S & $S$ & $S$ & $S$ & $S$ & M & $S$ & $P i-k^{s}$ \\
\hline Kanto 51 & M & S & $S$ & $\mathrm{R}^{\mathrm{h}}$ & $\mathrm{R}^{\mathrm{b}}$ & $\mathrm{R}^{\mathrm{b}}$ & $\mathrm{R}^{\mathrm{h}}$ & $P i-k$ \\
\hline Fujisaka 5 & $\mathrm{M}$ & S & $\mathrm{M}$ & $S$ & M & $\mathrm{M}$ & M & $P i-i, \quad P i-k^{s}$ \\
\hline Aichi Asahi & $S$ & $S$ & $\mathrm{R}$ & $S$ & $\mathrm{~S}$ & $S$ & $\mathrm{R}$ & $P i-a$ \\
\hline K 1 & S & $S$ & $\mathrm{M}$ & M & $\mathrm{M}$ & M & $\mathrm{S}$ & $P i-t a$ \\
\hline Pi No. 4 & $S$ & M & $\mathrm{MR}$ & $\mathrm{MR}$ & $\mathrm{MR}$ & MR & M & $P i-t a^{2}$ \\
\hline
\end{tabular}

Inoculated by injection method.

* : No gene identified up to date, although the presence or absence of $P i-k^{s}$ was not tested.

to be controlling resistance for the second fungus strain.

Highly and intermediately resistant plants of the fifth population in Table 2 showed for the second inoculation a segregation agreeing with a ratio of $4: 1$ which was expected under the condition where one of the two genes controlling the resistance to the first fungus strain controlled also the resistance to the second.

In the other 3 populations, segregation ratios obtained for the second inoculation did not agree with the expected ratio under the condition where the gene for the second inoculation was independent of the gene for the first. This suggests that a common gene controls the resistance to the two fungus strains. Sasashigure has already been known to carry the resistance gene $P i-a$ (Kryosawa, 1967 a, 1968 a). The results obtained here, therefore, suggest the possibility that a common gene controls the resistances to Ken 54-04, Ken 54-20, Ina 168, Hoku 1 and P-2 b. Besides this an additinoal gene that controls the resistance to Hoku 1 may be present in HR-22.

The results of $\mathrm{F}_{2}$ analysis of the hybrid of HR $-22 \times$ Koshiji Wase are shown in Table 3 . The $\mathrm{F}_{2}$ populations showed monogenic segregation for Ina 168 and Ken 54-20 and digenic segregation for Hoku 1 in the first inoculation. These results conformed with those obtained in the $F_{2}$ population of $H R-22 \times$ Sasashigure. In the second inoculation, plants belonging to $r$ class for Ina 168 showed a segregation ratio of $15: 1$. This does not necessarily indicate an independence between genes controlling resistance to the two strains, because of rather low reliability of the $F_{2}$ analysis of this hybrid as mentioned above. The experimental result of the second population suggests that a common gene controls the resistance to the two fungus strains, Ken 54-20 and P-2 b, conforming to the suggestion obtained in the hybrid of HR- $22 \times$ Sasashigure. The digenic segregation of third population for Ken 54-04 in the hybrid of HR- $22 \times$ Koshiji Wase was different from the monogenic segregation of the hybrid of HR-22 and Sasashigure. With the exception of this, the segregations of the hybrid of HR-22 $\times$ Koshiji Wase can be explained by the genic constitution in HR-22 presumed in the analysis of HR- $22 \times$ Sasashigure; that is, one and the same gene controls the resistance to P-2 b, Ken 54-20, Ken 54-04, Ina 168 and probably Hoku 1 and another gene controls the masked(hypostatic) resistance to Hoku 1. However, the experimental results mentioned above are not adequate to indicate the relationships between resistance genes for Hoku 1 and other four fungus strains.

$\mathrm{F}_{3}$ analysis was done mainly to clarify this point. Eighty-five lines of $\mathrm{F}_{3}$ generation of the hybrid of HR- $22 \times$ Sasashigure were inoculated with Hoku 1 and P-2 b at a week interval (Table 4). The results showed a good agreement between segregations for the two fungus strains except for four lines which showed a segregation to Hoku 1 but not to P-2 b. 


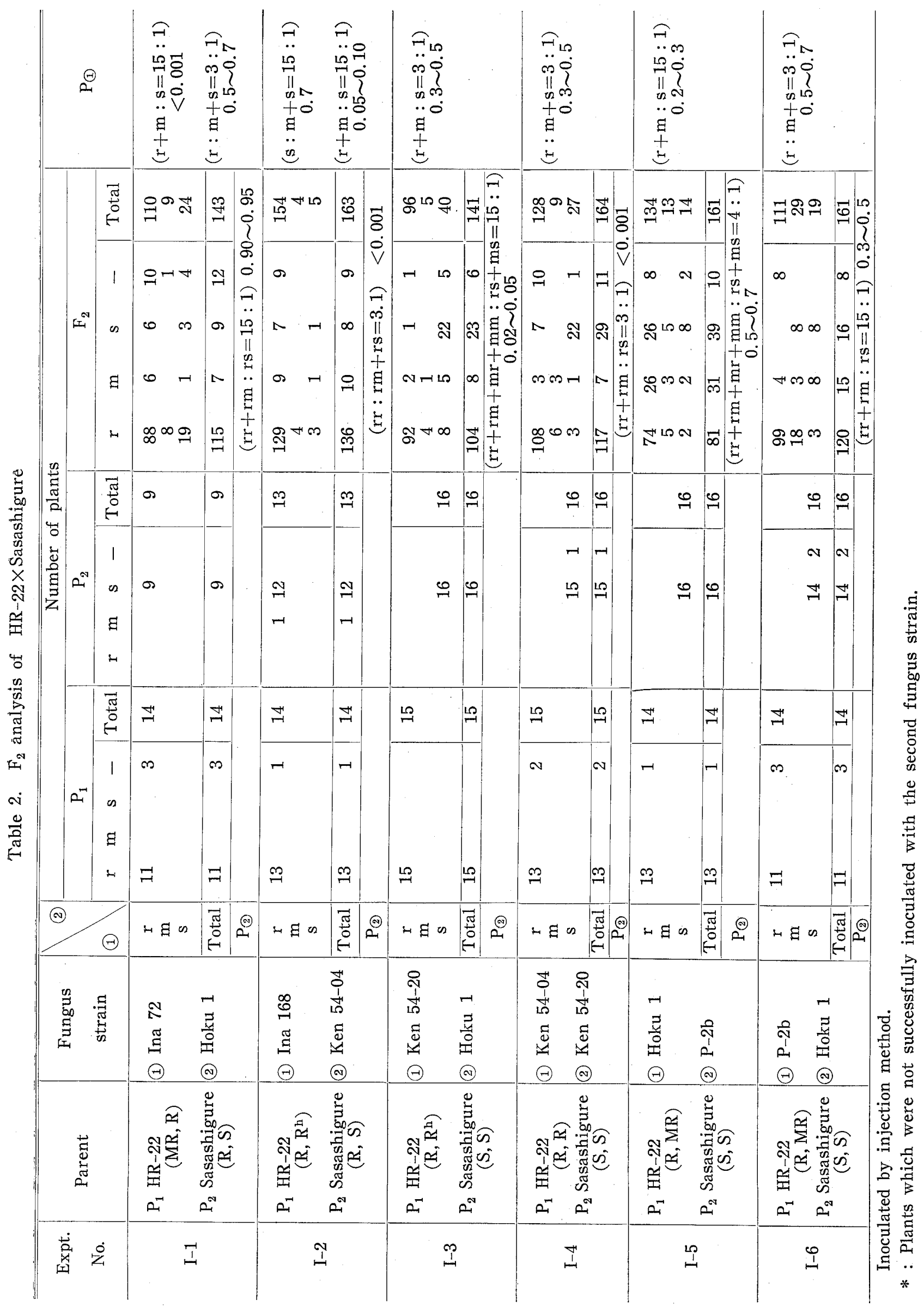


Table 3. $F_{2}$ analysis of $\mathrm{HR}-22 \times$ Koshiji Wase

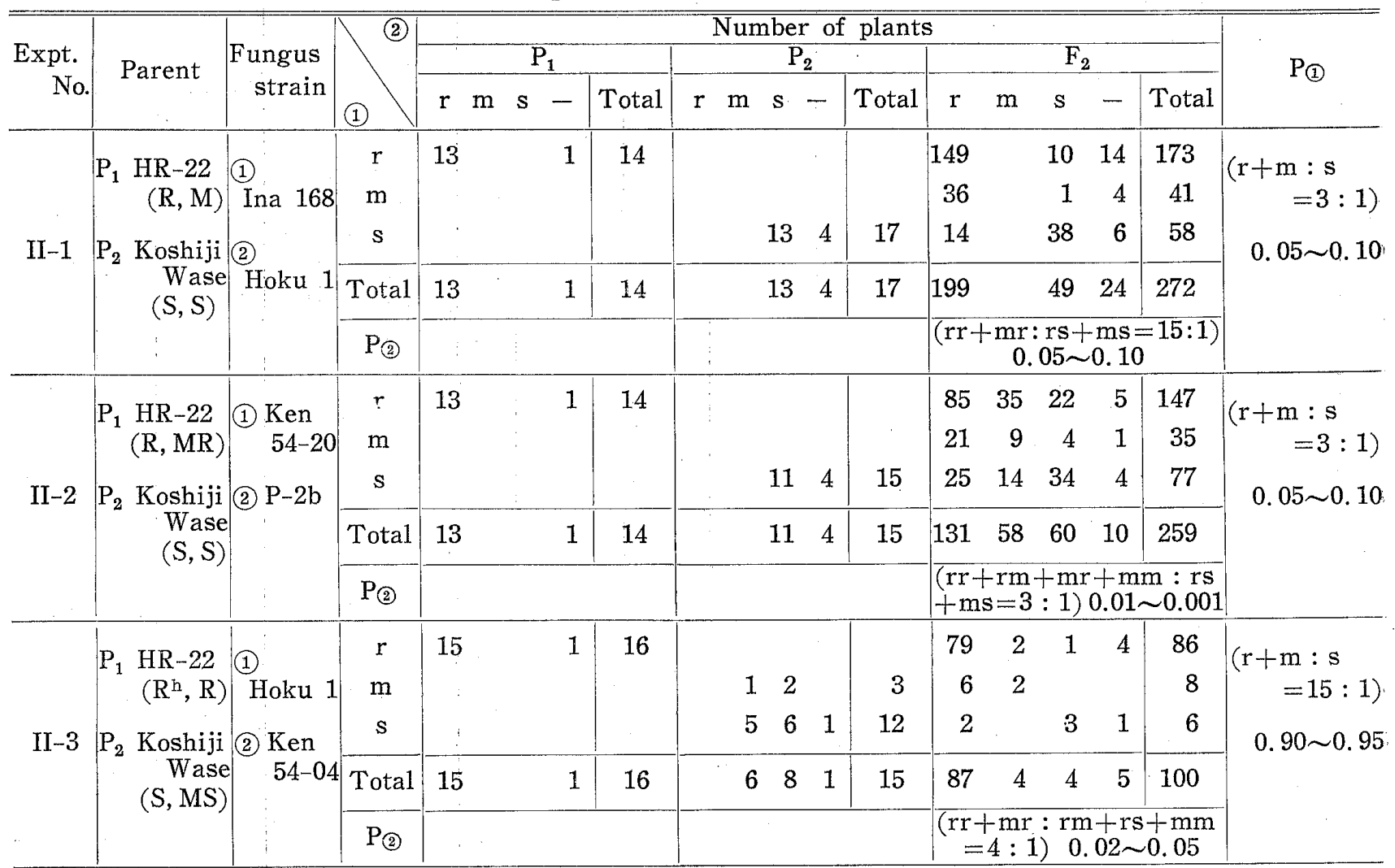

Inoculated by injection method.

Table 4. $\mathrm{F}_{3}$ analysis of $\mathrm{HR}-22 \times$ Sasashigure

\begin{tabular}{|c|c|c|c|c|c|c|c|c|}
\hline \multirow{2}{*}{$\begin{array}{c}\text { Expt. } \\
\text { No. }\end{array}$} & \multirow{2}{*}{ Parent } & \multirow{2}{*}{$\begin{array}{l}\text { Fungus } \\
\text { strain }\end{array}$} & \multirow[b]{2}{*}{ (1) } & \multicolumn{4}{|c|}{ Number of lines } & \multirow{2}{*}{$\mathrm{P}_{(1)}$} \\
\hline & & & & $\mathrm{r}$ & seg & $\mathrm{s}$ & Total & \\
\hline \multirow{5}{*}{ III } & \multirow{5}{*}{$\begin{array}{r}\mathrm{P}_{1} \mathrm{HR}-22 \\
(\mathrm{R}, \mathrm{R}) \\
\mathrm{P}_{2} \text { Sasashigure } \\
(\mathrm{S}, \mathrm{S})\end{array}$} & \multirow{5}{*}{ (1) Hoku 1} & $\mathbf{r}$ & 22 & 4 & & 26 & \multirow{5}{*}{$\begin{array}{l}(1: 2: 1) \\
\quad 0.3 \sim 0.5\end{array}$} \\
\hline & & & seg & & 37 & $2 z$ & 31 & \\
\hline & & & & & & & & \\
\hline & & & Total & 22 & 41 & 22 & 85 & \\
\hline & & & $\mathrm{P}_{(2)}$ & \multicolumn{4}{|c|}{$(1: 2: 1) \quad 0.90 \sim 0.95$} & \\
\hline
\end{tabular}

Twenty lines including these four lines were further tested with P-2 b, Hoku 1, Ken 54-04 and Ina 168, with a complete agreement among segregations to the four fungus strains.

B) Selection of lines which showed reactions different from HR-22 from the hybrid progenies of $\mathrm{HR}-22 \times$ Sasashigure.

As mentioned in the previous paper (KiYoSAWA, $1968 \mathrm{a}$ ), gene analysis of the hybrid of japonica and indica types is difficult by the usual procedurès consisting of simple hybridization and inoculation of the $\mathrm{F}_{2}$ or $\mathrm{F}_{3}$ progenies, due to complication of segregation and partial sterility in the $F_{1}$ and later generations.
Therefore, an effort was made to select lines which differ from HR-22 in reactions to seven fungus strains, P-2 b, Ken 53-33, Ina 72, Hoku 1, Ken 54-20, Ken 54-04 and Ina 168. Later, selected lines were tested for resistance to the seven fungus strains, and classified on the basis of their resistance (Table 5). The classification was not so clear as the one observed in the hybrid progenies of Pusur $\times$ Norin 22 (Kiyosawa, $1969 \mathrm{~b}$ ), because there were many lines of intermediate types of resistance.

A considerable unavoidable difficulty was experienced especially in classification among ,$+ c$ and $d$ types in Table 5. Genealogical 
Table 5. Reactions of selections from the progeny of the hybrid of HR-22 and Sasashigure to the seven fungus strains

\begin{tabular}{|c|c|c|c|c|c|c|c|}
\hline \multirow{2}{*}{ Type of selections } & \multicolumn{7}{|c|}{ Fungus strain } \\
\hline & $P-2 b$ & Ken $53-33$ & Ina 72 & Hoku 1 & Ken $54-20$ & Ken 54-04 & Ina 168 \\
\hline $\mathrm{a}$ & $S$ & $S$ & $\mathrm{R}$ & $S$ & $S$ & $M \sim S$ & $\mathrm{R}$ \\
\hline $\mathrm{b}$ & $\mathrm{M}$ & S & $\mathrm{S}$ & $\mathrm{R}$ & $\mathrm{R}$ & $\mathrm{R}$ & $\mathrm{R}$ \\
\hline c & $S$ & $\mathrm{~S}$ & $\mathrm{~S}$ & M & $S$ & M & $S$ \\
\hline d & M & M & M & M & M & M & M \\
\hline$a b$ & M & $\mathrm{S}$ & $\mathrm{R}$ & $\mathrm{R}$ & $\mathrm{R}$ & $\mathrm{R}$ & $\mathrm{R}$ \\
\hline$a d$ & M & M & $\mathrm{R}$ & M & M & M & $\mathrm{R}$ \\
\hline a c & $\mathrm{S}$ & S & $\mathrm{R}$ & $\mathrm{M}$ & S & $M$ & $\mathrm{R}$ \\
\hline$b d$ & $\mathrm{M}$ & M & $\mathrm{M}$ & $\mathrm{R}$ & $\mathrm{R}$ & $\mathrm{R}$ & $\mathrm{R}$ \\
\hline$a b d$ & M & M & $\mathrm{R}$ & $\mathrm{R}$ & $\mathrm{R}$ & $\mathrm{R}$ & $\mathrm{R}$ \\
\hline+ & $S$ & $S$ & $S$ & $\mathrm{~S}$ & $S$ & $M \sim S$ & $S$ \\
\hline
\end{tabular}

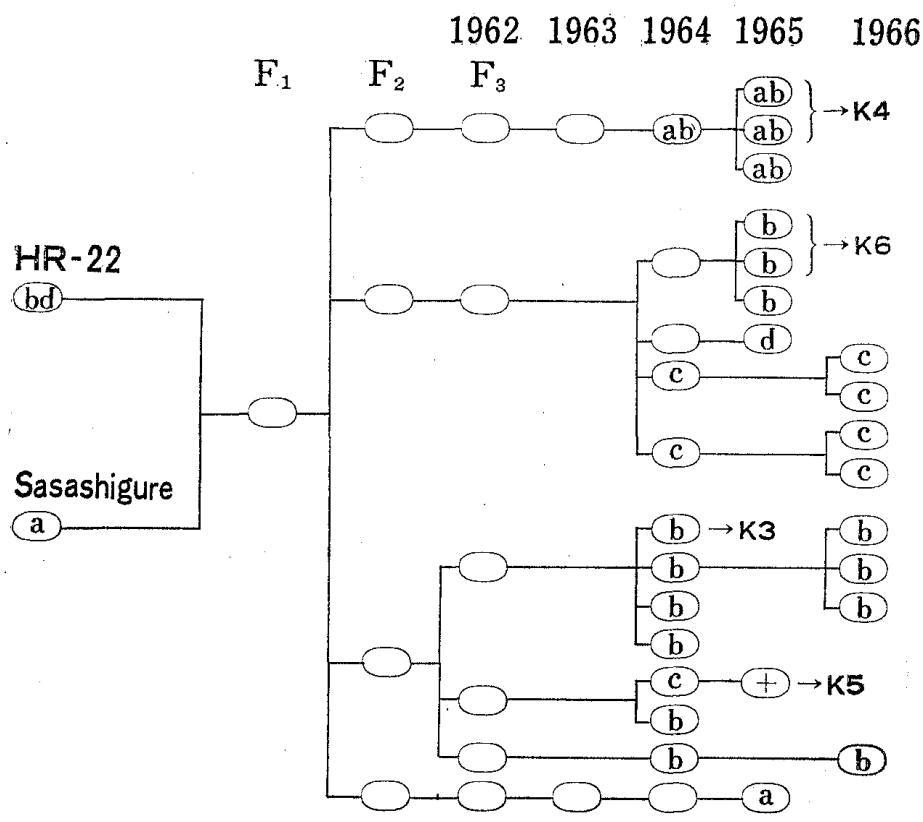

Fig. 1. Genealogical relationship and resistance of selections from progenies of the hybrid of HR $-22 \times$ Sasashigure.

relationship and type of resistance of the selected lines are shown in Fig. 1.

C) Gene analysis of K 3 by hybridization method.

K 3 is one of selected lines as shown in Fig. 1, and shows $\mathrm{b}$ type of resistance. $\mathrm{K} 3$ was crossed with varieties, Shin 2, Kanto 51, Fujisaka 5, Aichi Asahi, K1 and Pi No. 4. Genic constitution for resistance of these varieties is shown in Table 1.

$\mathrm{F}_{2}$ populations of these hybrids were inoculated with Ina 168 or Ken 54-20 (Table 6).
An $F_{2}$ population of the hybrid of Shin $2 \times \mathrm{K} 3$ showed monogenic segregation for Ina 168, indicating the presence of one gene controlling the resistance to Ina 168 . For the same fungus strain, no susceptible plants were found in an $F_{2}$ population of the hybrid of K3 with Kanto 51 . This indicates that the gene in $\mathrm{K} 3$ is the same or allelic to the gene $P i-k$ in Kanto 51. The digenic segregations in inoculation with Ina 168 for the hybrids of K 3 with Fujisaka 5 and Aichi Asahi indicate that the gene for resistance to Ina 168 behaves independently of the gene $P i-i$ in Fujisaka 5 and of the gene Pi-a in Aichi Asahi. The digenic segregations were also found in $F_{2}$ populations of the hybrids of $\mathrm{K} 3$ with $\mathrm{K} 1$ and $\mathrm{Pi}$ No. 4, when inoculated with Ken 54-20, indicating an independence between the gene for resistance to Ken 54-20 in K 3 and the two genes, $p i-t a$ in $\mathrm{K} 1$ and $P i-t a^{2}$ in $\mathrm{Pi}$ No. 4.

One hundred and eighteen lines of $\mathrm{F}_{3}$ generation of the hybrid of Shin $2 \times \mathrm{K} 3$ were, in separate experiments, inoculated with Ken 54-20 and Ken 54-20-k+. The latter was a mutant, which changed to attack the gene $P i-k$ from Ken 54-20. The inoculation with Ken $54-20-k^{+}$was carried out in order to know the participation of the gene Pi-k in K 3 . If only the gene $P i-k$ participates in resistance 
Table 6. $\quad F_{2}$ analysis of the hybrid of $\mathrm{K} 3$ with some varieties

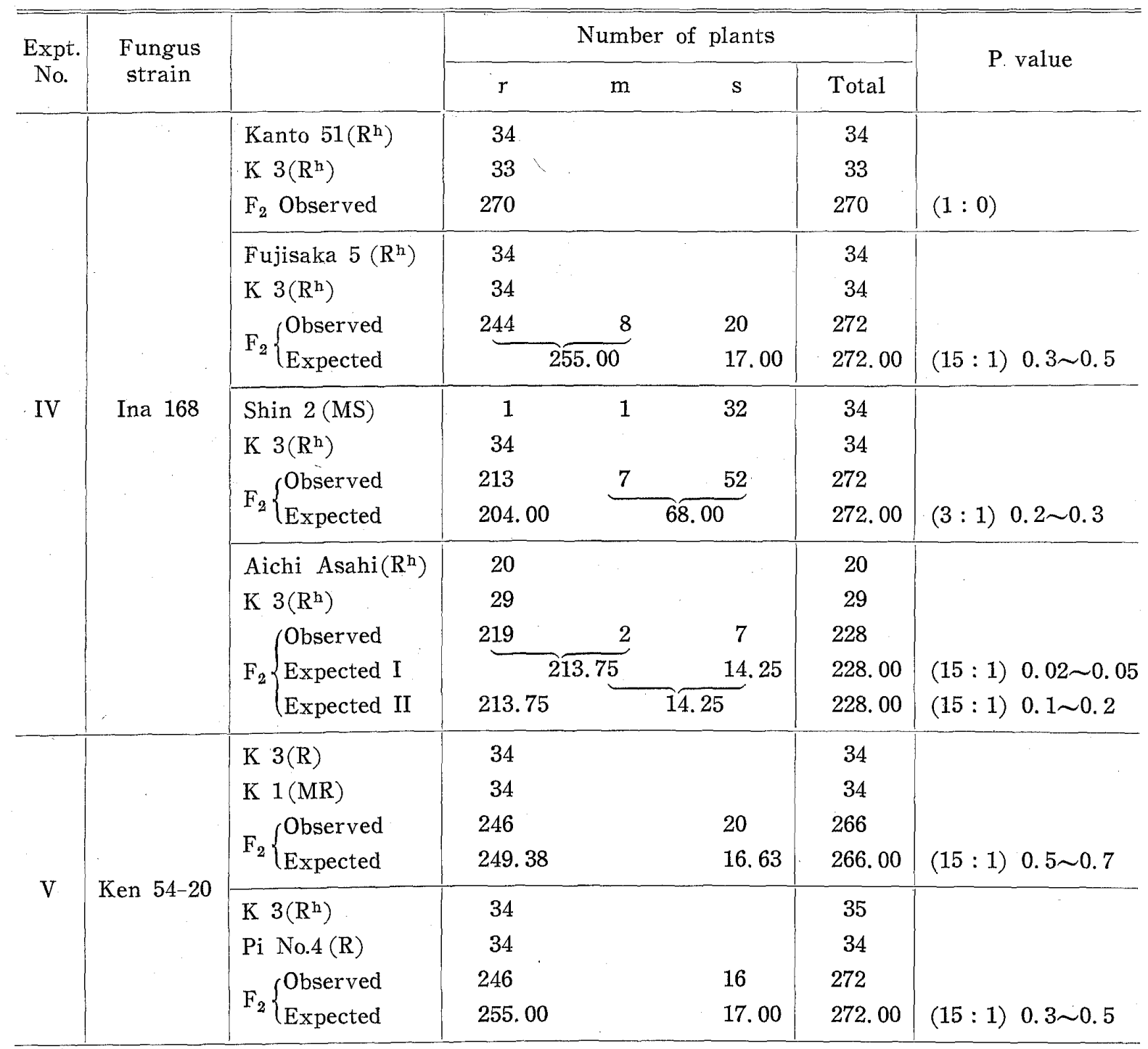

Inoculated by spraying method.

Table 7. Reactions of $F_{3}$ lines to two fungus strains in Shin $2 \times \mathrm{K} 3$

\begin{tabular}{|c|c|c|c|c|}
\hline \multirow{2}{*}{$\begin{array}{l}\text { Expt. } \\
\text { No. }\end{array}$} & \multirow{2}{*}{ 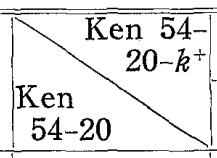 } & \multicolumn{2}{|c|}{$\begin{array}{c}\text { Number of } \\
\text { lines }\end{array}$} & \multirow{2}{*}{$P$ value } \\
\hline & & $r$ & Total & \\
\hline \multirow{3}{*}{$\begin{array}{l}\mathrm{VI} \sim \\
\mathrm{IX} * *\end{array}$} & $\mathrm{I}^{*}$ & 185 & $\begin{array}{r}185 \\
51\end{array}$ & \multirow[t]{2}{*}{$\begin{array}{c}(3: 1) \\
0.2 \sim 0.3\end{array}$} \\
\hline & Total & 18551 & 236 & \\
\hline & $P$ value & \multicolumn{2}{|c|}{$(3: 1) 0.2 \sim 0.3$} & $\left(\begin{array}{c}\mathrm{rr}: \mathrm{ss}=3: 1) \\
0.2 \sim 0.3\end{array}\right.$ \\
\hline \multicolumn{5}{|c|}{$\begin{array}{l}\text { *: } r \text { shows lines in wh } \\
\text { resistant. } \\
\text { * : A half of lines were } \\
\text { with one fungus stra }\end{array}$} \\
\hline
\end{tabular}

to Ken $54-20$ in K 3, the inoculation with Ken $54-20-k^{+}$should bring a change of segregation as compared with the inoculation with Ken 54-20. Such a change was not found (Table 7).

D) Gene analysis of HR-22 and $K 3$ by mutant method.

Mutant method for gene analysis was effectively used in the previous paper (KIYosawA, $1967 \mathrm{~b}, 1968 \mathrm{~b}, 1969 \mathrm{~b}$ ), in which varieties to be tested were inoculated with fungus mutant and their original strains. HR-22 and $\mathrm{K} 3$ showed similar reactions to Kanto 51 type varieties to the seven fungus strains, which have exclusively been used for tests of resistance by Kiyosawa. Therefore, HR-22 (Table 8) and $\mathrm{K} 3$ (Table 9) were tested by the mutant method, with some varieties containing a Kanto 51 type variety. HR-22 and K 3 did not show any different reaction for some 
Table 8. Test for resistance of HR-22 with fungal mutants in comparison with Kanto 51

\begin{tabular}{|c|c|c|c|c|c|c|}
\hline \multirow{2}{*}{ Variety } & \multicolumn{6}{|c|}{ Fungus strain } \\
\hline & Ken $54-20$ & Ken-54-20- $\mathrm{k}^{+}$ & Ina 168 & Ina $168-\mathrm{k}^{+}$ & Ken 54-04 & Ken $54-04-\mathrm{k}^{+}$ \\
\hline Kanto 51 & $\mathbf{R}^{\mathrm{h}}$ & $\mathbf{S} *$ & $\mathbf{R}^{\mathrm{h}}$ & $\mathbf{S}$ & $\mathbf{R}^{\mathrm{h}}$ & $\mathbf{S}$ \\
\hline HR-22 & $\mathrm{R}$ & M & $\mathrm{MR}$ & M & $\mathrm{R}$ & $\mathrm{R}$ \\
\hline Expt. No. & \multicolumn{4}{|c|}{$\mathrm{X}$} & \multicolumn{2}{|r|}{ XI } \\
\hline
\end{tabular}

Inoculated by injection method.

* : Gothic letter shows a significant difference in the reactions to two fungus strains.

Table 9. Test for resistance of K 3 with fungal mutants in comparison with some differential varieties

\begin{tabular}{|c|c|c|c|c|c|c|c|c|c|c|c|c|c|}
\hline \multicolumn{2}{|c|}{ Variety } & \multicolumn{12}{|c|}{ Fungus strain } \\
\hline & Genotype* & $\begin{array}{l}\text { Ken K } \\
54-20\end{array}$ & $\begin{array}{c}\text { en } 54- \\
20-k^{+}\end{array}$ & $\begin{array}{l}\text { Ken K } \\
54-04\end{array}$ & $\begin{array}{c}\text { en } 54- \\
04-k^{+}\end{array}$ & $\begin{array}{l}\text { Ina I I } \\
168-k\end{array}$ & $\begin{array}{l}168- \\
k^{+}-a^{+}\end{array}$ & $\begin{array}{l}\text { Ken K } \\
54-20\end{array}$ & $\begin{array}{l}\text { en } 54- \\
20-k^{+}\end{array}$ & $\begin{array}{r}\text { Ina } \\
72\end{array}$ & $\begin{array}{l}\text { Ina } \\
72-a^{+}\end{array}$ & $\underset{168}{\text { Ina In }}$ & $\begin{array}{l}\text { a } 168- \\
a^{+}-k^{+}\end{array}$ \\
\hline Shin 2 & $P i-k^{s}$ & $S$ & S & M & M & $S$ & $S$ & $\mathrm{~S}$ & $S$ & $S$ & S & $S$ & $S$ \\
\hline Aichi Asahi & $P_{i-a}$ & $S$ & $S$ & MS & MS & $\mathbf{R}$ & $\mathbf{S}$ & $S$ & $S$ & $\mathbf{R}$ & $\mathbf{S}$ & $\mathbf{R}$ & $\mathbf{S}$ \\
\hline Kanto 51 & $P i-k$ & $\mathbf{R}^{\mathrm{h}}$ & $\mathbf{S}$ & & & & . & $\mathbf{R}^{\mathbf{h}}$ & $\mathbf{S}$ & S & S & $\mathbf{R}^{\mathrm{h}}$ & $\mathbf{S}$ \\
\hline Kusabue & $P i-k$ & & & $\mathbf{R}^{\mathrm{h}}$ & $\mathbf{M}$ & $S$ & S & & & & & & \\
\hline Fujisaka 5 & $P i-i, P i-k^{s}$ & MS & MR & M & $\mathrm{MR}$ & M & M & $\mathrm{S} * *$ & $\mathrm{~S}$ & $\mathrm{~S}$ & S & $S$ & MS \\
\hline $\mathrm{K} 1$ & $P i-t a$ & MR & $\mathrm{M}$ & M & MR & S & S & M & M & $\mathrm{M}$ & M & $S$ & $\mathrm{~S}$ \\
\hline Pi No.4 & $P i-t a^{2}$ & MR & $\mathrm{MR}$ & $\mathrm{R}^{\mathrm{h}}$ & $\mathrm{R}^{\mathrm{h}}$ & $\mathrm{R}$ & $\mathrm{R}$ & M & MR & $\mathrm{R}^{\mathrm{h}}$ & MR & $\mathrm{R}$ & $\mathrm{MR}$ \\
\hline Ou 244 & $P i-z$ & MR & $\mathrm{MR}$ & MR & $\mathrm{MR}$ & $\mathrm{M}$ & M & M & M & $\mathrm{M}$ & M & M & M \\
\hline K 2 & $P i-a, P i-k^{p}$ & $\mathbf{R}$ & $\mathbf{S}$ & $\mathbf{M}$ & $\mathbf{S}$ & $\mathbf{R}$ & $\mathbf{S}$ & $\mathbf{M}$ & $\mathbf{S}$ & $\mathbf{R}$ & $\mathbf{S}$ & $\mathbf{R}$ & $\mathbf{S}$ \\
\hline K 3 & $?$ & $\mathrm{R}$ & MR & $\mathrm{R}^{\mathrm{h}}$ & $\mathrm{M}$ & $\mathrm{M}$ & $\mathrm{R}$ & $\mathrm{M}$ & M & $S$ & $S$ & $\mathrm{M}$ & M \\
\hline \multicolumn{2}{|c|}{ Expt. No. } & \multicolumn{2}{|c|}{ XII } & \multicolumn{4}{|c|}{ XIII } & \multicolumn{6}{|c|}{ XIV } \\
\hline
\end{tabular}

Inoculated by injection method.

* : Showing that resistance gene (s) are not detected except for the described gene (s) among genes identified up to date, $P i-a, P i-k, P i-i$ (YAMASAKI and KIYOSAWA, 1966), Pi-ta (KIYOSAWA, 1966), $P i-t a^{2}$ (KIYOSAWA, 1969), $P i-z$ (KIYOSAWA, 1967), $P i-k^{s}$ (KIYOSAWA, 1969), Pi-m(KIYOSAWA, 1968), and $P i-k^{p}$ (KIYOSAWA, 1969).

**: The gene $P i-i$ does not show resistant reaction in late autumn or winter season when injection method was used.

mutant and their original strains. This indicates that they do not carry the allele Pi-k.

\section{Discussion}

In the first-half of the present study, it was suggested that HR-22 has at least two genes for the resistance to blast. One may control the resistances to five mong the seven strains, P-2 b, Hoku 1, Ken 54-20, Ken 54-04 andIna 168, and the other controls the resistance to Hoku 1. The function of the former gene is similar to that of the gene Pi-k. It is, however, very difficult to obtain correct information on the genic constitution for resistance from $F_{2}$ analysis of indica $\times$ japonica crosses, because there is generally no clear-cut segregation.
An effort to separate the genes in HR-22 indicated that Kanto 51 type lines (YamASAKI and Kiyosawa, 1966) were derived from the hybrid progeny of HR $-22 \times$ Sasashigure. This also leads us to the suggestion that HR-22 carries $P i-k$ itself or its analogue. In order to know the relationship between the $P i-k$ and the gene in HR-22, a derivative from the hybrid of HR- $22 \times$ Sasashigure, K 3, was studied by the hybridization method for gene analysis. The hybrid progeny of K 3 with Kanto 51 carrying $P i-k$ did not show segregation of susceptible plants. This suggests that $\mathrm{K} 3$ has $P i-k$ itself or its allele, as K 3 was demonstrated to have only one gene for resistance to the fungus strain used, Ken 54-20. On the 
Table 10. Reactions of multiple alleles at the $P i-k$ locus to several fungus strains

\begin{tabular}{|c|c|c|c|c|c|c|c|c|c|c|c|c|c|}
\hline \multirow{2}{*}{$\begin{array}{c}\text { Multiple } \\
\text { allele }\end{array}$} & \multicolumn{13}{|c|}{ Fungus strain } \\
\hline & $\mathrm{P}-2 \mathrm{~b}$ & $\begin{array}{l}\text { Ken } \\
53-33\end{array}$ & Ina 72 & Hoku & $1 \underset{1-k^{+}}{\mathrm{Hoku}}$ & $\begin{array}{r}\text { Ken K K } \\
54-20\end{array}$ & $\frac{\operatorname{len} 54-}{20-k^{+}}$ & $\begin{array}{c}\text { Ken } 54- \\
20-k h^{+}\end{array}$ & $\begin{array}{c}\text { Ken } 54 \\
04\end{array}$ & $\begin{array}{c}\text { Ken } 54- \\
04-k^{+}\end{array}$ & Ina 168 & $\begin{array}{l}\text { Ina } 168 \\
a^{+}-k^{+}\end{array}$ & $\begin{array}{l}\text { Ken } \\
\mathrm{Ph}-03\end{array}$ \\
\hline$P i-k$ & M & $S$ & $S$ & $\mathrm{R}^{\mathrm{h}}$ & S & $\mathrm{R}^{\mathrm{h}}$ & $S$ & S & $\mathrm{R}^{\mathrm{h}}$ & $S$ & $\mathrm{R}^{\mathrm{h}}$ & $S$ & $\mathrm{R}^{\mathrm{h}}$ \\
\hline$P i-k^{s}$ & $S$ & $S$ & $\mathrm{~S}$ & S & $S$ & $S$ & $S$ & $S$ & $S$ & $S$ & S & $\mathrm{S}$ & $\mathrm{R}^{\mathrm{h}}$ \\
\hline$P i-k^{p}$ & $S$ & $S$ & S & $\mathrm{R}$ & $S$ & $\mathrm{R}$ & $S$ & $S$ & $\mathrm{R}$ & $S$ & $\mathrm{R}$ & S & $\mathrm{R}$ \\
\hline$P i-k^{h}$ & M & $S$ & S & $\mathbf{R}$ & $S$ & $\mathrm{R}$ & MR & S & $\mathrm{R}$ & $\mathrm{R}$ & $\mathrm{R}$ & $\mathrm{R}$ & MR \\
\hline
\end{tabular}

Injection method

other hand, the results by the mutant method for gene analysis indicated that HR-22 and $\mathrm{K} 3 \mathrm{had}$ an allele or gene different from $\mathrm{Pi}-\mathrm{k}$.

The $\mathrm{F}_{3}$ analysis of the hybrid of Shin $2 \times$ $\mathrm{K} 3$ indicated that segregation for Ken 54-20 was the same as one for Ken $54-20-k^{+}$, a mutant in which the avirulence allele $A v-k$ changed to $A v-k^{+}$These results lead to the conclusion that the gene in HR-22 and K 3 is not the same as the gene Pi-k but is allelic to it.

This gene in HR-22 and $\mathrm{K} 3$ differs in reactions to mutants with changed $A v-k$ locus from the gene $P i-k$. In the $P i-k$ locus, three alleles have been found; $P i-k$ (Yamasaki and Kiyosawa, 1966), $P i-k^{s}$ (Kiyosawa, $1969 \mathrm{a}$ ) and $P i-k^{p}$ (Kiyosawa, $1969 \mathrm{~b}$ ). The allele in HR-22 and $\mathrm{K} 3$ is different from any of these three. Therefore, the allele found in HR-22 and K 3 will be symbolized as $P i-k^{h}$. The reactions of these four alleles to several fungus strains are shown in Table 10.

\section{Summary}

High resistance of the Indian rice variety HR-22 to many Japanese strains of the blast fungus was genetically analysed. Genetic complexity of the resistance of this variety made the analysis difficult. Therefore, a derivative from an HR- $22 \times$ Sasashigure hybrid, $\mathrm{K} 3$, was analysed in respect of blast resistance. The result of hybridization for gene analysis of resistance indicated that $\mathrm{K} 3$ and so HR-22 has the gene $P i-k^{h}$ which was allelic to the $P i-k$. The allele $P i-k^{h}$ was differentiated from the allele $P i-k$ on the basis of reactions to mutants virulent to varieties having $P i-k$.

\section{Literature Cited}

KIYOSAWA, S., 1967 a. Breeding of blast-resistant rice variefies and inheritance of blast-resistance. Shokubutsu Boeki 21 : 145 152. (In Japanese)

KIYOSAWA, S., $1967 \mathrm{~b}$. The inheritance of resistance of the Zenith type varieties of rice to the blast fungus. Japan. J. Breed. $17: 99 \sim 107$.

KIYOSAWA, S., 1968 a. Genetic studies on hostpathogen relationship in the rice blast diseases. Rice Diseases and Their Control by Growing Resistant Varieties and Other Measures. 137 153. Tokyo.

KIYOSAWA, S., 1968 b. Inheritance of blast-resistance in some Chinese rice varieties and their derivatives. Japan. J. Breed. $18: 193 \sim 205$.

KrYOSAWA, S., 1969 a. Inheritance of resistance of rice varieties to a Philippine fungus strain of Pyricularia oryzae. Japan. J. Breed. $19: 61 \sim 73$.

KIYOSAWA, S., 1969 b. Inheritance of blast-resistance in West Pakistani rice variety, Pusur. Japan. J. Breed. $19: 121 \sim 128$.

KIYOSAWA, S., 1969 c. Inheritance of blast-resistance of the rice variety Yashiro-mochi. Agr. Hort. $44:$ 407 408. (In Japanese)

YAMASAKI, Y. and S.KIYOSAWA, 1966. Studies on inheritance of resistance of rice varieties to blast. I. Inheritance of resistance of Japanese varieties to several strains of the fungus. Bull. Natl. Inst. Agr. Sci. D 14 : 36〜69. (In Japanese)

\section{インドのイネ品種 HR-22 のいもち病抵抗性の遺伝}

清沢茂 久・V.V.S. Murty

（農業技術研究所）

インドのイネ品種 HR-22 の日本のいもち病菌菌系に 対する抵抗性の遺伝子分析を行なつた。HR-22 は少な くとも 1 つの主働遺伝子をも 対立遺伝子で要り，Pi-k $k^{h}$ と名付けられた。これはこれ
までに発見され命名された 10 番目の遺伝子であり, $P i-k$ 遺伝子座上の複対立遺伝子として見いだされた 4 番目の遺伝子である。 